\title{
Is the past really not what it used to be?
}

Citation for published version (APA):

Birner, J. (1995). Is the past really not what it used to be? METEOR, Maastricht University School of Business and Economics. METEOR Research Memorandum No. 021 https://doi.org/10.26481/umamet.1995021

Document status and date:

Published: 01/01/1995

DOI:

10.26481/umamet.1995021

Document Version:

Publisher's PDF, also known as Version of record

\section{Please check the document version of this publication:}

- A submitted manuscript is the version of the article upon submission and before peer-review. There can be important differences between the submitted version and the official published version of record.

People interested in the research are advised to contact the author for the final version of the publication, or visit the DOI to the publisher's website.

- The final author version and the galley proof are versions of the publication after peer review.

- The final published version features the final layout of the paper including the volume, issue and page numbers.

Link to publication

\footnotetext{
General rights rights.

- You may freely distribute the URL identifying the publication in the public portal. please follow below link for the End User Agreement:

www.umlib.nl/taverne-license

Take down policy

If you believe that this document breaches copyright please contact us at:

repository@maastrichtuniversity.nl

providing details and we will investigate your claim.
}

Copyright and moral rights for the publications made accessible in the public portal are retained by the authors and/or other copyright owners and it is a condition of accessing publications that users recognise and abide by the legal requirements associated with these

- Users may download and print one copy of any publication from the public portal for the purpose of private study or research.

- You may not further distribute the material or use it for any profit-making activity or commercial gain

If the publication is distributed under the terms of Article $25 \mathrm{fa}$ of the Dutch Copyright Act, indicated by the "Taverne" license above, 


\title{
Is the past really not what it used to be?
}

\author{
Jack Birner \\ University of Maastricht \\ University of Trento
}

The history and methodology of economics used to have a somewhat dull image among economists. This is because economists did not turn reflective on the subject they practised until they were safely past the age of retirement. This has changed since methodology and the history of economic thought have attracted scholars who migrated from economics at a more pristine age. Both disciplines have greatly benefited from this rejuvenated interest. New historical results are presented, and new methodological positions are tested against them. What has developed out of this is a renewed discussion about the correct way of doing intellectual history.

An author who has made considerable contributions both to the history and the methodology of economics is E. Roy Weintraub. Weintraub is a multiple academic migrant. His first field of specialization was mathemathics, his second economics, and his latest the methodology and history of economics. Over the last fifteen years he has published three books that are of interest for several reasons. They present new material from the recent history of economics. An important part of the relevance of these results derives from the light they throw on present-day economics. What gives a considerable added value to Weintraub's work is that he has shifted his methodological position. Each book marks a further step in this development. Weintraub uses the latest developments in the methodology of economics in each subsequent study. As the development of methodology in its turn reflects the state of the debate in the philosophy of science, Weintraub's combination of methodology and history offers a unique sequence of palettes of philosophical ideas about the correct way of writing history. Underlying his work is the quest for a philosophy of historiography.

In 1979 Weintraub published a book on the relation between micro- and macro-economics, Microfoundations. The subtitle reveals the methodological emphasis of the book: The compatibility of microeconomics and macroeconomics. The author's methodological position may be characterized as LakatosianPopperian:

I consider economic theory to be a scientific discipline. .. I believe that progress occurs in 
terms of sequences of models which have assumptions that are clear and conclusions that are falsifiable either by empirical tests or by tests of congruence with other theoretical constructs. (Weintraub 1979: vii) ${ }^{1}$

The historical chapters of the book deal with the development of the neo-Walrasian programme in general-equilibrium theory, with Keynes, and with the evolution of the neo-Walrasian synthesis. In the spirit of Popper and Lakatos, Weintraub's revealed intention is to contribute to the further progress of contemporary economics by clearing the way for the integration of micro- and macro-economics.

1985 saw the appearance of Weintraub's General equilibrium analysis; Studies in appraisal. If Microfoundations still seemed to waver between popper and Lakatos, its successor leaves no doubt as to its methodological credentials. Its rational reconstruction of the history of the notion of the existence of equilibria makes explicit and extensive use of Lakatos' methodology of scientific research programmes. This is purely a study in methodology, and the author no longer has the pretension to make a direct contribution to economic theory.

After another six-year interval, Weintraub has added a third volume to this series, on the development of economic stability analysis. He claims that this time he has traded in the Lakatosian approach for social constructivism. This is reflected in the title, Stabilizing dynamics; Constructing economic knowledge.

Weintraub's historical work has steadily improved with each subsequent book. His latest book in particular has all the qualities that make for good history: high information content, novelty, speculation, thrill, and a sense of relevance. Even though the historical analysis is inspired by particular historiographical and philosophical ideas, it stands firmly on its own. This makes it accessible to readers from a wide variety of backgrounds. Perhaps Weintraub's major significance lies in the fact that he has contributed to the awareness among contemporary economists that the economics of the 1930s has shaped modern economics, and continues to do so to this very day. His work has helped to put the history of economics back on the agenda of economists. ${ }^{2}$ This is no mean accomplish-

1 However, Weintraub's later constructivism already filters through in a passage on p. 160: "Economic knowledge is constructed piece by piece, using partial explanations which are better fitted into the nooks and crannies of our discipline than other partial explanations. Models are metaphors, explaining one structure in terms of another. ... Barring logical error, the value of a model depends on the purposes of its use by the economist whose understanding of the economy is always in terms of those metaphors most congenial to his mind."

2 Weintraub is not alone in this, but the company he keeps, though distinguished, is still not very large. It 
ment, and Weintraub is to be commended on it. But this still leaves the question unanswered whether Weintraub's progression from Popper via Lakatos to social constructivism constitutes progress in historiography.

I will address this question by examining Weintraub's claim that his latest book is an exemplar of social constructivism. I shall argue that in fact Weintraub has never left behind his Lakatosian and Popperian principles, and that his work is none the worse for it. In order to do so, I shall first discuss the history that Weintraub presents. Most of the critical comments will be reserved for the second and third parts of this article, which discuss the ideas underlying Weintraub's way of doing history, and the philosophical ideas behind it all.

\section{History}

My dear sir, allow me to say this to you", said Codicil at last, "To understand thought, you must first understand thinking, and where it occurs. In the mind and in history. To understand history, you must first have experienced it. I will confess to you I think you understand neither one of these things. There is a saying: to think greatly, you must also err greatly. I do not say Criminale erred. But we are talking of a great mind, the Nietzsche of our long, dark, dying century. We cannot presume even to begin to advise such a man, a man bigger than men, how to understand history, or interpret it correctly. We may merely observe how he has chosen to understand it. Do you follow me? Malcolm Bradbury, Doctor Criminale

Few economists and historians of economics will doubt the influence of Samuelson's Foundations. It has to a large extent shaped their ideas of economics as a discipline. According to Weintraub, its influence went even deeper. It also shaped the views of the history of economics. The habitual history of stability theory tells the story of the gradual discovery of the truths of the Foundations. Weintraub makes it his explicit purpose to avoid this approach, which he characterizes as Whig historiography. For reasons that I will give later, I prefer to speak of the Faraday effect. The term is Peter Munz', who coined it after Faraday's observation that he would describe his own results "not as they were obtained, but in such a manner as to give the most concise view of the whole." (quoted in Munz 1985: 96). Munz speaks of an "honest bias" of the historian of science as the compiler of source material, because he

includes Leijonhufvud and Patinkin. 
is honestly disinterested in the historical process and pre-selects his material to present unhistorical evidence. This kind of pre-selection predisposes the historian to evaluate past science relative to the present state of scientific knowledge rather than relative to contemporary alternatives. (Munz 1985: 96)

This is just the sort of historiography Weintraub criticizes. He is opposed to the idea that this is the only valid approach to the history of economics. His alternative accounts (for he offers several) are designed to show what the development of the study of stability in the 1930s looks like when we take off the "Foundational" spectacles. Chapter 2 discusses a number of economists on whose work Samuelson drew. Weintraub pays attention to the specific problems they addressed, or thought they addressed. This is then compared with Samuelson's interpretation. Weintraub argues that the interpretation of Robbins' work as being concerned with the distinction between statics and dynamics is only one way (Samuelson's) of interpreting it. Samuelson interpreted Robbins as dealing with dynamic processes, whereas Robbins was concerned with the largely methodological question of how to proceed from the abstract notion of a static equilibrium to that of a dynamic equilibrium, which has more factual content.

Frisch' interest in dynamics was part and parcel of his study of business cycles. Because of the Faraday-effect of Samuelson's Foundations this background has been all but forgotten. Weintraub is certainly correct to observe that
the Frisch concern with untangling the systematic from the accidental, trend from cycle, was a long way from the issues associated with market problems like the nature and robustness of particular price- quantity configurations. Again, the desire on the part of later writers to see Frisch as leading to Samuelson, because Samuelson used the Frisch work in his own analysis, forced the past to look more like the present. (23)

Tinbergen's concerns are different again. Weintraub argues that for Tinbergen "the mathematical understanding of dynamics is the only understanding of dynamics." (24). Tinbergen once described the way in which economic problems are solved by mathematical means as "the night train", thus indicating the general lack of knowledge, or perhaps his own lack of interest into what goes on. Tinbergen shows himself to be a naïve rationalist (this is my term, not Weintraub's) in his view on the relation between mathematics and economics. According to this position, which is shared by the majority of economists and historians and philosophers of science, there is a clearly distinguishable, non-fuzzy boundary between economics and

3 Mere page references are all to Weintraub 1991. 
mathematics. They stand in a master-servant relationship. Economics and mathematics cooperate in a number of neatly separable discrete steps. First there is an economic problem. This is then translated into mathematics. After that, the appropriate mathematical tools are applied to solve the mathematized problem. And finally, the mathematical solution is retranslated into economics, where it solves the original, economic problem. In reality, however, economics and mathematics are often engaged in a much more complicated intercourse on board Tinbergen's night train, one which may produce economically nonsensical offspring, or lead to a change in the original problem. ${ }^{4}$ Curiously enough, this is hardly ever acknowledged by economists and historians and methodologists of economics.

Hicks, whose work is a major source of influence on Foundations, differs from Frisch and Tinbergen in that his interest in dynamics and stability finds its origin in economics rather than statistics or mathematics. Initially influenced by Hayek's intertemporal general equilibrium theory, Hicks stressed the role of expectations in a monetary economy. Weintraub discusses in detail how the mathematics that Hicks used structured his ideas about stability. His choice of the mathematical apparatus of Jacobian matrices led to the paradoxical result that whereas Hicks thought he was doing dynamics, in fact his "formal analysis (as opposed to the verbal exposition) was entirely concerned with the character of equilibrium positions." (35; italics deleted). Weintraub traces the two different lines along which the later literature on dynamics developed, and which were not joined until the $1960 \mathrm{~s}$ (and then only partially), to two core components of the work of Hicks: on the one hand the stability of competitive equilibrium, and growth and capital theory on the other. The former was to shape the bulk of the literature through the influence of Samuelson, who reconstructed Hicks' stability analysis in a model that was shaped by the economics of Frisch and the mathematics of what was later recognized to be Liapunov stability theory.

Keynes is the last of the pre-Foundational economists Weintraub discusses. He suggests that the enormous confusion about the message of the General Theory hails from Samuelson's way of translating the $1930 \mathrm{~s}$ ideas about equilibrium, statics and dynamics into a mathematical model. Interpreting the General Theory in neo-Walrasian terms is just one among many possible interpretations, and it is not the historically correct one as it interprets Keynes via texts that had yet to be written when Keynes constructed his theory. Weintraub mentions Leijonhufvud's reconstruction in a Marshallian context with approval because it attempts to understand Keynes in the light of earlier texts, ones which may have influenced Keynes.

Microfoundations already contains a few (not very profound)

4 Examples of this are given in Birner forthcoming. 
observations on the role of mathematics in general equilibrium theory. ${ }^{5}$ Weintraub's following book pays more attention to this. It closes with a brief chapter in which the author sketches his thoughts on the relations between economics and mathematics. We can now see that Weintraub formulated a research programme which is carried out in the third book in the sequence. The relation between economics and mathematics is one of the most important problems it addresses, and a wealth of material is brought to bear on this. Chapter 3 examines the non-economic literature that helped shape the collection of articles that found their way, in 1947, into Foundations. Samuelson got his ideas and techniques from a variety of sources. Lotka's Elements of Physical Biology is one of these, and it is largely from this book that Samuelson took over the way to model the relation between statics and dynamics that later became associated with his name. Although Lotka knew the work of mathematical economists such as Cournot, Jevons, Edgeworth and Pareto, and dealt explicitly with economics in his book, it is one of the ironies of intellectual history that "his influence on economics was indirect, through his mathematical modelling, and not direct, through his analysis of the economy of nature." (48). A point Weintraub could have made at this point but does not is that naïve rational-reconstructivist historians of science might see here more than an accident. They might argue that the fact that Lotka's mathematics was developed in part to deal with his economics of nature was an objective reason why it found its way into Foundations. (A different reconstruction of this episode of the development of stability theory might accuse samuelson of deliberately suppressing references to Lotka's discussion of economics in order to appear more original.)

Apart from the applied mathematics of Lotka, Samuelson also used the work of pure mathematicians, notably Birkhoff and Picard. Picard makes use of Liapunov stability theory. This was to play an important role in the economic literature on stability of the 1950s. Samuelson uses the method of Liapunov, but he does not refer to Liapunov's work, although he does refer to Picard's book, in which Liapunov is discussed. This causes Weintraub to raise the following sequence of questions.

If Samuelson did not read the relevant pages of the work of Picard, why did he not? If Samuelson read the relevant pages in the work of Picard, why did he not cite them in the same manner in which he cited the other passages from Picard. And if he did read the relevant pages of Picard's book, why did he not read Liapunov, for Picard's footnote gave a clear reference in French to the major work of Liapunov? (55)

One possible answer to the why-not-Liapunov question, viz. that Samuelson did not read French well, is confirmed by

5 On pp. 160-1. 
Samuelson's close colleague Robert Solow. An answer that Weintraub finds deeper and more interesting is that samuelson's interest in stability was only derivative, as he may have considered it to be a tool to be used in comparative static analysis. Weintraub finds this a plausible answer, but in its turn it raises the question where samuelson's concern with comparative statics and his relative neglect of stability theory came from. Weintraub indicates that part of the answer to that question is to be found in the influence that the work of the mathematical physicist and statistician E.B. Wilson had on Samuelson. That Samuelson neglected the analysis of stability and instead paid more attention to comparative statics was an accidental and unintended consequence of the mathematical form in which he chose to present economic theory, a form that was suggested to him by Wilson. Wilson was a student of the physicist Gibbs, who stood in a theoretical tradition in thermodynamics that considered equilibrium conditions more important than stability analysis.

This is a thrilling detective story. Weintraub shows that Samuelson had the opportunity to do stability analysis, and that the means were readily available to him. So why didn't he use them? Literary criminology suggests that we look more closely into his motive. Weintraub chooses not to simply accept Samuelson's interest in comparative statics as sufficient, and starts looking for ulterior motives. I wonder whether this is required. Let us look at what Samuelson states are the "fundamental purposes" of his Foundations. This can be found on pages $3-6$ of the 1983 edition. The first purpose is to unify the various sub-disciplines of economics into one formal framework. The second main objective is to identify the meaningful theorems in these various fields. Meaningful theorems (the meaning of which I will not go into) are derived from two types of general hypotheses. For the analysis of individual economic units it is the hypothesis that equilibrium conditions are equivalent to the conditions for the maximization or minimization of some variable. For an economic system as a whole it is the hypothesis that the system is in stable equilibrium or motion. So far, this would seem to point clearly to the centrality of the notion of stability, and Weintraub's sense of wonder at Samuelson's relative neglect of it in the technical part of his analysis is entirely understandable. But then Samuelson goes on to remark: "The plausibility of such a stability hypothesis is suggested by the consideration that positions of unstable equilibrium, even if they exist, are transient, non-persistent states, and hence on the crudest probability calculation would be observed less frequently than stable states. How many times has the reader observed an egg standing upon its end?" (Samuelson 1983, p. 5). It seems that this, together with the correspondence principle that samuelson proudly presents as a way of dealing with dynamics through comparative statics, constitutes the motive, and answers the question satisfactorily. Samuelson has made the conscious choice of not going into the details of formal stability analysis. After all, one cannot examine everything at the same time. The appeal to plausibility is not 
at all unusual for economists, even though from a methodological point of view Samuelson's pre-Columbian argument (or rhetoric) deserves critical attention. I fully understand the thrill Weintraub must have felt when raising his series of conditional why-not questions. They are what makes historical research so fascinating. But $I$ wonder if in this particular case he has not let himself be carried away, well, if not by Whiggism, then at least by the lure of the treasure of possibilities which hindsight, "that most useful of the instruments of the historian" (Finley 1977: 104-5) allows us to discover.

I present my interpretation reluctantly because I like Weintraub's better. My alternative assumes a conscious decision on the part of Samuelson not to problematize stability. I agree that the answers to Weintraub's questions are of interest because they might clarify "the interrelationships between the mathematical literature and the applied literature" (55) - IF (big if), that is, the suppositions underlying the questions are true. In that case (and in that case only) Weintraub's story would indeed make a strong case for the non-neutrality of mathematics. I will return to matters of truth and falsehood in historical analysis in the last part of this article. However, the hypothesis that mathematics is not the sort of tool or machine that one can switch off and on at will to let it do exactly what one wants finds support in other case studies in the book. These are to be found, inter alia, in chapter 4. It zooms in on Liapunov theory, which shaped theorizing about economic stability from the 1950s. The chapter throws further light on the relationship between economics and mathematics by discussing the importance of the timing of developments in these fields, and the related matter of priority claims. The claims that have been advanced for Maurice Allais being the first, in 1943, to use Liapunov analysis, are effectively refuted. Here Weintraub shows himself a meticulous historian who is constantly aware of the dangers of seeing the past through the spectacles of later developments. Weintraub's care in treating the history of economics shows itself, too, in his account of the ways in which Liapunov theory was disseminated, from applications for war purposes through academic mathematics to applied mathematics and engineering and finally to mathematical economics. The conclusion Weintraub draws is very different from the naïve rationalist position. Tools and problems stand in a sort of dialectical relationship: "the economic conceptualizations selected the tools, and the mathematical tools selected the economic conceptualization." (96).

Chapter 5 shows how ideas about equilibrium evolved between 1939 and 1954. Throughout the 1930s Hayek had been struggling to construct a dynamic theory of the business cycle on the foundations of the static general equilibrium theory of Walras and Pareto. Hicks was well acquaintanted with Hayek's work. Earlier in the 1930s he had tried to get a formal grasp of Hayek's notion of equilibrium but failed. In Value and Capital of 1939 he undertook a renewed attempt to come to terms with equilibrium. Hicks now distinguished two incompatible concepts, one which sees equilibrium as the outcome of a market 
process, the other as a set of conditions characterizing a rest point, and he tried to bridge the gap between the two. Samuelson did not believe there was an incompatibility. To his mind, the mathematical apparatus which he derived from the work of Lotka and Birkhoff and used to model equilibrium unified both concepts. For Hicks equilibrium was an idealization that was central to a theory that was to depict reality by means of a sequence of approximations to this idealized concept. For Samuelson equilibrium had no such function. He identified equilibrium with the solution to a set of equations. In the hands of Arrow and Debreu this was transformed into the notion of equilibrium as a balance between supply and demand. What Weintraub wants to make clear with this case study is that the idea (which he calls positivist) that equilibrium is a real state of the world and that economics tries to find ever better ways of describing this, is wrong. What really happens, according to Weintraub, is that the meaning of the word "equilibrium" changes as the context in which it is used changes. An important part in this process of meaning change is played by the different metaphors which are associated with the different pieces of mathematics that are used. I will come back to this later.

\section{Historiography}

- C'est votre histoire... répétait Jef d'un ton
ironique.
- C'est l'histoire que je choisirais si j'étais à
votre place... Parce que, dans ce cas, la mort de
Willems deviendrait presqu'un accident...
- Ça est un accident... Simenon, Maigret et le clo-
chard

It is Weintraub's explicit purpose to present an alternative to what he calls Whig historiography, which sees progress in the development of ideas, i.e. a movement "from darkness to light, from prose to model" (p. 10). In contrast to this, Weintraub wants to "show that there are many other ways to read these papers and that it is not foolish to read the record as being discursively rich, confused, and hardly ever convergent on any coherent perspective." ( $p .10)$ In this he has succeeded convincingly. Weintraub emphasizes that no particular state in the history of economics that a particular reconstruction shows texts to lead to is privileged. "Meaning does not reside in texts, no[r] is it to be found. Meaning is provided by readers who come to a text with histories of their own, both personal and social." (37). Thus, as Weintraub demonstrates, review articles are especially important in shaping our present view of a discipline. It has been observed (notably by Hayek - cp. for instance Hayek 1974) that economists sorely lack a sense of self-relativization. Considering the fact that after nuclear physicists economists are the most dangerous species of scientists in that their advice may (and has) cost millions of lives, chapter 7 alone ought to be compulsory reading for all students of economics. It discusses 
Negishi's 1962 Econometrica review article, and shows that the way in which Negishi presented the material is in large part responsible for shaping ideas both of the history and of the further course of research of stability. Among other things, the article led to a forgetting Clower's work on stability.

Weintraub's other case studies demonstrate how different theoretical backgrounds led to different theories. Whether this is best analyzed in terms of the meanings of words is an issue that I wil return to in the last section, on philosophy. You see that I am already incurring new debts of explication to the reader even before the old ones that I have already accumulated have been redeemed. It is high time to start doing something about that.

L'histoire: plus ça change, plus c'est la même chose

At the beginning of the previous section I made a distinction between the Faraday effect and the idea that it is the task of the history of science to show progress culminating in the present state of a subject. This is of more than terminological importance. Weintraub criticizes the Lakatosian method of rationally reconstructing the history of science as being Whiggish. If we look at Weintraub's objections to rational reconstructionism, we find two different arguments. One is that it imposes the preconceived notion that science makes progress towards the truth, which he says is connected with "a belief that Nature or Reality itself constrains the texts in such a manner that the texts can be read or reread as a sequence of moves in which science gets closer and closer to the Truth about Nature or Reality." (117). This is what Weintraub calls Whiggism. What is usually meant by Whig history is the selection of a history so as to defend a particular preferred position, one's own, as the best. And indeed, this position is inextricably bound up with the idea of progress. However, it is confusing to call every history that shows or postulates progress Whiggish. This is particularly the case with rational reconstructions. Even though rational reconstructionists sometimes or often (or always as is the case with Lakatos) say they are interested, on the meta-level, in progress, the method can perfectly do without assuming or postulating progress. There exist many rational reconstructions of other positions than the one that is (perhaps) favoured by the author who happens to carry out the reconstruction.

Doing history of science is very much like doing social science. It involves behavioural hypotheses, such as the one that scientists are motivated by progress as it is defined by Lakatos, or that their motive is to reach consensus, as Weintraub supposes (for instance on p. 145). The content of the motivational hypothesis may vary from one historiographical approach to another. However, the structure of the historical reconstruction remains the same:

All in all, the sum total of general laws available to the historian of science for his reconstruction 
of what actually happened is his estimate of human nature as it performs under certain cultural and economic constraints, plus the philosophy of science he holds to be correct; it cannot be the sources by themselves.... The historian of science...must have a view of his own which he cannot really derive from the sources themselves... This view must cover such matters as what scientists will do, how they will investigate, what puzzles them, how they regard their peers, whom they will take to be their peers, whose authority they will respect, how they will evaluate their inspirations, how they will treat their psychological hang-ups, what is likely to lead to an inspiration, and suchlike. (Munz 1985: 97-8)

The assumption of progress on the meta-level has to be distinguished from ascribing to actors, on the object level, the wish to make progress. In a Whig context "progress" is a value-laden word. But in the context of a rational reconstruction it is best considered to be a technical term, or a definition, on a par with "Pareto-improvement" in welfare economics. If a rational reconstruction separates the meta-level assumption of progress from the one on the object level, the difference with what Popper calls situational analysis (or the method of the logic of the situation) disappears. It is the approach Munz so clearly describes in the passage just quoted. The assumption of rationality it involves is the same as, for instance, the economist's, and the history that it produces is a rational reconstruction to the extent that the subjects really behave rationally in the economist's sense. However, histories of science are not even bound to assumptions of rationality. They usually take them as their starting point, but Iif a rational explanation is not satisfactory, the historian may look for irrational factors, as even Lakatos admits. ${ }^{6}$

Weintraub's second criticism of rational reconstructions is that they are "ex post rationalizations [which], though they stabilize the previous history, do not themselves present their knowledge contemporaneously with the historical action and actors." (10-11). In other words, they suffer from the Faraday effect. However, this is demonstrably not the case with many existing rational reconstructions. So, although Weintraub is critical of rational reconstructions, one may wonder if there is much substance to his criticism. Weintraub is critical of Lakatosian rational reconstructions to the point of constructing one himself, in chapter 6 , in order to compare it with the approach he now favours. But when I see how he goes about actually doing history, I have strong doubts as to whether this is so very different from the method of rational reconstruction. Take the discussion of the role of Lotka. Weintraub makes assumptions about "what Samuelson could have known" (48; emphasis added). He states that "it is reasonable to assume that Samuelson came to Lotka through Wilson" 
(58; emphasis added). It seems to me that Weintraub, if he is doing social-reconstructionist historiography at all, is doing virtual social construction. He constructs a fascinating narrative which uses inspired conjectures, assumptions about what is reasonable in a particular historical situation, biographical material, letters, and, of course, the written texts. All of these sources are used in rational reconstructions, too. Apart from the terminology and the decision about what should go into the text and what should be relegated to the footnotes, I do not see much difference between Weintraub's social constructions and rational reconstructions. Ascribing to economists the wish to reach consensus, as Weinraub does, is one possible hypothesis about the behaviour of scientists. If one analyzes the development in science from this perspective, the behaviour of individual scientists will be reconstructed rationally in the light of this hypothesis (even if the word "rational" is avoided). As I observed above, the content of the motivational hypothesis is different from the one advanced by Lakatos and his followers, but the structure of the historical reconstruction is the same. The motivational hypotheses, moreover, lend themselves to empirical tests.

Why is it that the case studies Weintraub presents look so much like rational reconstructions? Because it is notoriously difficult to be a consistently non-Whig non-Faraday historian of science! Back in 1952, when there was still reason to consider the history of science to be "Clio's stepchild", Dijksterhuis discussed such a "pure" position under the name of "the phenomenological method".

It consists in that one attempts to re-enact as well as possible the mental atmosphere of the period to be studied, to impose upon oneself the constraint of appealing only to the facts that were known at the time, to speak about them in the terminology of the period and to employ in one's calculations the methods of calculation then known. In so doing, one consciously suspends the value judgement that would have to be passed if it were our goal to test the ideas under examination against modern scientific insights. In particular, one is careful not to approach those ideas with the attitude of superiority, so disastrous for the study of history, that makes one speak benevolently of naïvité and helplessness and derogatorily of stupidity. (Dijksterhuis 1952: 260)

It is so difficult to follow this approach consistently that one may wonder if it can be done at all.

Dijksterhuis contrasts the phenomenological method with what he calls "evolutionism" (which is the Faraday approach), and he signals the same dangers that Weintraub sees as inherent in Whiggism: 
[I]t is particularly in this subject [the study of the evolution of the so-called Paduan method] that the methodical dangers that always threaten evolutionism in the history of science become readily apparent. Instead of posing the perfectly legitimate question whether there has been a continuous development, one postulates its presence. In the case of Oresme in particular the search to discover so-called precursors everywhere - a methodical weakness that is endemic in historians of science - has adorned this figure with modern features to the point of deforming his true stature in the light of later insights. Thus, the evolutionist lust for continuity time and again appears to need the rein of phenomenological reflection. (ibid.: 262)

Evolutionism and phenomenology cannot do without one another. There is no getting-away from it, not even for a self-declared anti-Whig historian such as Weintraub. And indeed, Weintraub does not advocate a purely phenomenological approach. He would probably even admit that all the dangers of the Faraday effect (or evolutionism), as Dijksterhuis puts it, "should not make us forget that in the final analysis the history of science is born from that lust [for continuity] and that it provides the impulse for historical research, even more so than the lust to indulge in the past." (Dijksterhuis, ibid.: 162)

Asking why-not questions as Weintraub does presupposes evolutionism, and perhaps even Whiggism. Why didn't Samuelson refer to and use a solution that was available in the work of Picard? It "could have saved Samuelson and other economists from twenty years of fumbling around not knowing how to prove stability theorems about economic equilibria." (54). Why wasn't Samuelson more concerned with stability (61-2)? Why didn't the "development of [stability] theory follow the logic of the mathematical theory in which it eventually was to be embedded" (123)? In passages such as these I find Weintraub at his very best, but it is there that he is furthest removed from his self-professed anti-Whig constructivism. Historical "why-didn't"-questions are counterfactuals. Asking them involves deliberately taking a different point of view, the historian's own or somebody else's, but never the one held at the time by the author whose work the historian now studies or reconstructs. It is inevitable that such questions presuppose an outsider's, non-contemporary perspective, and perhaps even a certain measure of Whiggism.

7 Though Weintraub does not put it in such bold words, the intention underlying his choice for the speculative-but-interesting answer over the true-but-dull one to the question why Samuelson did not refer to Liapunov is not so very different from Lakatos' preference for rational reconstructions over actual history. Cp. Lakatos 1971, p. 120: "One way to indicate discrepancies between history and its rational reconstruction is to relate the internal history in the text, and indicate in 
As Weintraub observes, completely satisfactory answers to these questions cannot be found (57). The answers depend on the decision what to keep in and what to leave out. Given his stated preference for rhetoricism, Weintraub's initial choice when discussing why samuelson did not pay more attention to stability analysis is surprisingly pre-post-modern: the writings that samuelson cites provide the answers. But then he adds that the context is always richer. He chooses to develop only one possible line of inquiry, one which enriches the analysis with "the requirement of coherence". In this passage he seems to refer to coherence as a meta-requirement: it is "one of the ways we appraise more general narratives", ( $p$. 57). This still does not sound particularly post-modern, but that changes later, when coherence is mentioned again: "The larger community, to be a community, requires its members to talk coherently about the economy." (146). Coherence is part of the way in which speech communities are defined. The definition of communities raises a problem that $I$ will adress later.

\section{Philosophy}

- Moi, je vous laisse dire, n'est-ce pas? Ils racontent ce qu'il leur plaît. Vous racontez ce qu'il vous plaît...

\section{Simenon, Maigret et le clochard}

In his criticism of historical positivism and his defence of a constructivist historiography Weintraub does not stand alone. He is in the company of E.J. Dijksterhuis, and of Karl Popper, neither of whom is mentioned by Weintraub. In the case of Dijksterhuis this may be a mere matter of oversight or lack of space. With Popper it is different. Weintraub tells us that he started to rethink the status of rational reconstructions when he was confronted with rhetoricism, a variant of social constructivism, at the Klant conference in Amsterdam in $1985 .{ }^{8}$ I was there, too, ${ }^{9}$ and $I$ was struck by the violence of the Popper-bashing that went on. After having been influenced by Popper, many not only turn away from him, but find it necessary to either vilify and trivialize Popper's work, or, as is the case with Weintraub, deliberately omit references to it where it would have been reasonable to give them. Why is this? This is an interesting question for an intellectual historian

the footnotes how actual history 'misbehaved' in the light of its rational reconstruction." I suspect that such choices are part of the temperament of historians who do interesting history.

8 The proceedings were published in De Marchi 1988.

9 I was asked to comment on Weintraub's Lakatosian reconstruction of an episode in the development of general equilibrium theory. 
(particularly of the social-constructivist kind). Perhaps the reason why Popper's insights are now so often brushed aside as trivial is that they have become common knowledge. The fact that their acceptance is the result of many a fierce intellectual battle in the past is conveniently forgotten. Or maybe it is through some Oedipal mechanism that intellectuals who owe much to Popper now bury him in vengeful silence.

Weintraub's silence on Popper is all the more striking as there are so many crucial issues on which they agree. This is the case with their general attitudes towards history:

[I]nterpretations may be incompatible; but as long as we consider them merely as cristallizations of points of view, then they are not. For example, the interpretation that man steadily progresses ... is incompatible with the interpretation that he steadily slips back or retrogresses. But the 'point of view' of one who looks on human history as a history of progress is not necessarily incompatible with that of one who looks on it as a history of retrogression; that is to say, we could write a history of human progress towards human freedom ... and another history of human retrogression and oppression ...; and these two histories need not be in conflict; rather, they may be complementary to each other, as would be two views of the same landscape seen from two different points. This consideration is of considerable importance. For since each generation has its own troubles and problems, and therefore its own interests and its own point of view, it follows that each generation has a right to look upon and re-interpret history in its own way, which is complementary to that of previous generations. After all, we study history because we are interested in it, and perhaps because we wish to learn something about our own problems...

To sum up, there can be no history of 'the past as it actually did happen'; there can only be historical interpretations, and none of them final; and every generation has a right to frame its own. But not only has it a right to frame its own interpretations, it also has a kind of obligation to do so; for there is indeed a pressing need to be answered. We want to know how our troubles are related to the past, and we want to see the line along which we may progress towards the solution of what we feel, and what we choose, to be our main tasks. (Popper 1973, Vol II: 267)

On specific issues Weintraub and Popper have very similar views, too. Popper is as much of an anti-Whig as Weintraub:

[O]ur intellectual as well as our ethical education is corrupt. It is perverted by the admiration of brilliance ... It is perverted by the romantic idea of the splendour of the stage of History on which we 
are the actors. We are educated to act with an eye to the gallery. (Popper 1973, Vol II: 275)

Weintraub emphasizes the inevitability of interpretation. Popper concurs: "History has no meaning" (Popper 1973, Vol. II: 269). He elaborates: "in history no less than in science, we cannot avoid a point of view; and the belief that we can must lead to self-deception and to lack of critical care." (Popper 1973, Vol. II: 261) I do not think Weintraub disagrees with this. I also think that Weintraub agrees with Popper that

this does not mean that all interpretations are of equal merit. First, there are always interpretations which are not really in keeping with the accepted records; secondly, there are some which need a number of more or less plausible auxiliary hypotheses if they are to escape falsification by the records; next, there are some that are unable to connect a number of facts which another interpretation can connect, and in so far 'explain'. (Popper 1973, Vol. II : 261)

For even though Weintraub says that "[w]e can, of course, reconstruct the past as we wish ..." (94), he cannot mean that reconstruction is a gratuitous affair. After all, he demonstrates that the claim that Allais was the first to apply Liapunov theory is not in accordance with the records. He uses plausible auxiliary hypotheses (about the mathematical dynamics Samuelson could have known, p. 48, and that it is reasonable to assume that he came to Lotka through Wilson, p. 58) to make his story convincing. And he demonstrates that his interpretation can connect a number of otherwise unconnected facts by abandoning the thesis that mathematics is neutral.

However, if we look at a formulation of Popper's that expresses the same thought in different words, I think we have come a long way in identifying what separates Weintraub from Popper. The inevitability of interpretations, says Popper, "does not mean, of course, that we are permitted to falsify anything, or to take matters of truth lightly. Any particular historical description of facts will be simply true or false, however difficult it may be to decide upon its truth or falsity." (Popper 1973, Vol. II: 261). For Popper the truth or falsehood of a historical account matters, and truth is defined in terms of correspondence with reality. Recognition of the fact that in history it is unusually difficult to separate false from true statements is no reason to give up the idea that historical reconstructions can be true or false. Weintraub on the other hand wants to leave truth and falsehood behind. Knowledge is a matter of social construction, interpretation, and meaning, and if he has a theory of truth at all, it is likely to be a coherence theory.

There is a core of truth in all this. Ideas shape our views of the world. If this is not a tautology, it is at the very least an obvious truth. However, in construct-speak this sensible 
idea becomes perverted into phrases of unnecessary obscurity such as:

by the end of the 1940s or the early 1950s, the economy itself had changed in the only meaningful sense [sic] in which that claim can be sustained. That is, discursive practice about the economy had been altered to allow simultaneous maintenance of the two claims that the economy was in equilibrium and that there were socially unacceptable levels of unemployment ... (125: emphasis added).

Mathematical tools and economic problems shape one another, Weintraub gives many convincing examples of this. But it is something completely different to say that "The new mathematical tool ... changed the economy itself as the economy had come to be differently problematized." (95-6) For this to be the case, the ordinary citizen would have to notice a change in the world once economists start analyzing it by different means, and I fail to see how this is possible. What people notice in matters economic are things like unemployment, interest rates and wage-freezes, not discursive practice. (They may, of course, feel the consequences of the discursive practice of economists, when it is acted upon by politicians.) If Weintraub had said that the problems or the theories or the models had changed under the influence of the mathematical tools that were used, this would both have been understandable and true. The apparent reason why Weintraub makes the above false claim is his anti-realism. He wants to avoid talking about "the economy" as a thing that exists independently of our cognitive activity even if it means sacrificing truth. This reminds me of the devious habits of old-fashioned language philosophers, who found (and if they are not all extinct still find) reality such a suspect notion that one had to purify one's language from any words referring to it. Talking about reality was simply not done. The only respectable thing to talk about was language. That language is, among other things, referential was conveniently forgotten because it raised too many problems. I know a philosopher who in his analytical days invariably showed overt signs of physical discomfort (sweating, fidgeting, nervous laughter) when forced to use such words as "real", "reality", and even "philosophy". (He is now a "real" philosopher, and in much better health.)

Weintraub often suggests that the fact that knowledge is the product of social construction implies that knowledge is nothing but social construction. I have two objections to this, one logical, the other empirical. The logical objection will be briefly dealt with. The step from: "there is no unique true reconstruction of the past" to: "truth does not matter in historiography" is a non-sequitur. In general, there is a pair of non-sequiturs that underlies social constructivism. ${ }^{10}$ From

10 The following draws on an argument of Alan Musgrave that to my knowledge has not been published. I thank Rob de 
the tautologous premise "You cannot talk about a talk-independent economy without talking about it"11 the conclusion is drawn: "Therefore, you cannot talk about a talk-independent economy." But this is invalid, as is any argument that derives a contingent statement from a tautology. Social constructivists compound this logical error by arguing from the invalidly derived conclusion that you cannot talk about a talk-independent economy to the statement: "a talk-independent economy does not exist", which is another non-sequitur.

We do not have to look very far for empirical arguments against the core of social constructivism. Weintraub's own book abounds with them. It contains a great number of examples of how particular mathematical theories imposed contraints on the process of theory construction, even though this was no one's intention. This demonstrates that in the science of economics, as in ordinary life, there are unintended consequences of human actions and decisions. This effectively refutes the thesis that knowledge is purely a matter of construction. Unintended consequences of mathematical theorems, being unintended, have to be discovered. Therefore Weintraub's objective that "[w]e must seek to leave "discovery" in the history of economics in favor of interpretation, or hermeneutics" (118) is unattainable. His social constructivism is not guilty of the charge of being constructivist in the sense that Hayek gives to that word.

The same type of objection may be raised against the statement (on p. 127) that "the papers in that sequence [of mathematized argumentation about the stability of equilibrium] could well be understood as an attempt to show that that process was a social process of negotiation and argument." However, the autonomous influence of mathematics is more than a matter of the social negotiation of meaning. Each mathematical tool carries with it its own set of constraints. If it did not, it would be powerless. Meaning is a central concept in social constructivism, and it also plays a role in Weintraub's description of the influence of mathematics on economics in terms of metaphors. ${ }^{12}$ I have argued elsewhere that this is based on a justificationist theory of mathematics which is untenable. ${ }^{13}$ I will just point out another argument against the possibility that meanings become stabilized. It is that every

Vries for conveying the argument to me.

11 This seems to me a fair translation of the passage on p. 125, already quoted by me, and p. 127, where Weintraub says: "To say that economists negotiate the meaning of the economy is not to claim that the economy does not exist: It is not comprehensible to me what such a claim could even mean; we have no language to discuss such silliness." (emphasis added).

12 Pace Mirowski 1989.

13 Cp. Birner 1993. 
set of statements has infinitely many consequences, and therefore unintended consequences, too. We literally do not know what we talk about, as Popper puts it.

Though I agree with most of Weintraub's historical account of the notion of equilibrium of chapter 5, I have several objections to make to his conclusions. First of all, the philosophy of science which Weintraub calls positivist would better be characterized as naïve realism. This is the idea that theories are direct descriptions of reality. What is naive about this view is that in reality theories make use of idealizations, and that the way in which these are connected with reality is a problem that is only very partially understood. Of course, for a non-realist like Weintraub the problem does not arise because he does not consider theories to be descriptive at all. But how are the advantages of such a denial to be weighed against the disadvantages? I agree with social constructivists that "[r]epresentation [in theories, models, etc.] is a creative, purposeful human act" (151). However, their explanation of the effectiveness of scientific activity seems to me to suffer from hubris if "act" in the following quotation is read as "act succesfully": "communities that can agree on representations and descriptions can jointly act on their created world." (ibid.). A speech community that has created a conceptual world in which there is no gravity may find it hard to survive in a mountainous environment. The meaning theory of knowledge and science held by social constructivists makes the fact that theories are applicable to reality incomprehensible.

Where lies the meaning of it all?

Now, you may ask, why do I spend so much time criticizing the philosophical ideas behind a historical analysis that I find so much to praise in? If Weintraub or anyone else is inspired by social constructivism and produces such excellent history, isn't that justification enough? And is realism, the philosophy often believed to underly rational reconstructions, without problems? Can't we leave philosophical comparisons aside, and see what is left to decide between the two historiographical approaches that Weintraub contrasts? Well, yes, to a certain extent. Of course, each approach imposes its own constraints, and the fit will never be perfect. Push here and a bulge emerges on the other side. One of the bulges that Weintraub's constructivist history fails to contain is that economists hardly ever speak in terms of interpretations or the reaching consensus on the meaning of concepts. Instead, they use terms such as "meaningful theorem", "explanation", "prediction", and "description". On the other hand, a naïve-realist rational reconstruction does not know what to do (or even fails to notice) the many examples of the non-neutrality of mathematics in economics. There is an element of sound competition to this "battle of the bulges": by their fruits they shall be judged. Well, certainly, as long as this is not interpreted as the ends justifying the means. That sort of methodological instrumentalism, I find, is going too far. A methodology can never be justified with an appeal to its results only. For instance, it may be said that if there is nothing else to decide between 
the hermeneutic and the rationality approaches, it makes sense to choose that approach which most closely follows and takes seriously the arguments of scientists themselves. Economists talk about truth and description, and not about meaning or meaning changes or the stabilization of meaning. This would count against social constructivism. But then on the other hand, economists also have their mouths full of words like "empirical testing". There is no way around it: at the methodological level choices have to be made. Methodology is no mere mirror of scientific reality.

Weintraub uses his case studies as a defence of social constructivism, and that does not go through. I have already argued that what Weintraub does is much more like rational reconstructivism than he wants to make us believe. Now someone might argue that without a social-constructivist framework we would have remained deprived of the many valuable things Weintraub's history brings us. I find the examples of the nonneutrality of mathematics among the most important things of the book. But even if Weintraub's analysis of his case studies is an instance of social constructivism, social constructivism is not necessary for discovering it. Weintraub's analysis of the interaction between mathematics and economics has a counterpart in the analysis of physics by a philosopher who employs a different framework, Elie Zahar. ${ }^{14}$ Zahar is one of the few philosophers of science who sees an interesting problem here. ${ }^{15}$ He comes to the same conclusion as Weintraub: mathematics and science are so closely related that one can no longer speak of separate tools and problems. The difference is that Zahar says he is studying the logic of discovery. Terminology apart, I do not think this is a fundamental difference. Zahar, who stands in the tradition of Popper, Meyerson and Kant, readily admits the constructive element in scientific knowledge. But he also shows how mathematics has an autonomous influence on the direction in which scientific theories develop. That stepping outside a social-constructivist framework does not make the problem of the relation between mathematics and science disappear is also illustrated by the articles Wigner and Popper devoted to it. ${ }^{16}$

I even doubt whether Weintraub's analysis is an instance of social constructivism. His reconstruction of the history of

14 Cp. Zahar 1980 .

15 Fortunately, a growing (yet still small) company of students of the history and methodology of economics starts buying tickets for Tinbergen's night train to see what is happening on board. Mirowski's More heat than light is probably the best-known recent example. In the last few years methodologists in The Netherlands have addressed the same subject. Cp. Boumans 1993, Van Zijp \& Visser 1993, and Birner 1993 and forthcoming.

${ }^{16}$ Cp. Wigner 1960 and Popper 1963a. 
stability theory relies on elements that transcend construction. The fact that each particular piece of mathematics that is applied carries with it particular constraints is precisely what causes the original economic problems to be transformed. This phenomenon of problem drift (as I have called it elsewhe$r \mathrm{e}^{17}$ ) shows that scientific knowledge is not purely a matter of construction. The application of tools has unintended consequences which are only gradually discovered. ${ }^{18}$ Unintended consequences are part of the human condition. In science, as in life, "[m]an is not and never will be the master of his fate" (Hayek 1979: 176; emphasis deleted). This is precisely the reason why it is important to keep one's options open, to have alternative views to the accepted ones. But offering alternatives is not all there is to acquiring knowledge. Knowledge is more than a matter of conversation, edification and Sprachethik. Man has to live in and come to terms with a world that is not his own creation. This involves the struggle to survive, and survival is more than a gratuitous or free act of construction. That is why criticism is so important in science. Social-constructivist accounts of knowledge lack this evolutionary aspect. This is in part because the constructivist criticism of realism is aimed at the wrong target. It identifies the realist theory of knowledge with the idea that knowledge is a mirror of reality. But as Munz has so well argued (in Munz 1985), since Kant realists are interested in what goes on behind the mirror. The human cognitive apparatus is part of the evolutionary process of survival.

Even if we grant that science is a matter of the social construction of meaning, there is still a problem left for social constructivism. It concerns the notion of a language community. What words mean is constructed by the members of a particular community. How is membership of a community defined?

\begin{abstract}
The larger community, to be a community, requires its members to talk coherently about the economy. Coherence was obtained by sharing a vision of the economy ... This required a transformation of experience and an ordering of that experience; that ordering gave substance to the new rules of the language game called modelling the competitive economy. (146)
\end{abstract}

But if the visions one has are the product of a community, and membership of that community is defined by the visions one shares, then this is circular and one cannot explain why Samuelson or anyone else defined equilibrium as he did by

17 Birner 1993a: 132

18 The matter of unintended consequences seems to lie at the controversy over ad-hocness and novel facts. Unintended consequences also have a large role to play in debates about scientific realism. But there is no room here to elaborate these remarks. 
pointing out that he was part of a particular speech community. ${ }^{19}$

Conclusion

Weintraub's latest book sets a very high standard for the historiography of economics. It is one of the most thorough studies of the interaction between mathematics and economics that exists. It shows to what extent what is now considered to be the substance of an important sub-discipline in economics (and hence of economics as a whole) is the result of complex and contingent developments in the past. However, the metahistorical conclusions Weintraub draws from his historical analysis are not tenable, nor is the philosophical framework he says supports his historiography. I have argued that the author does not practice what he preaches. Of course, from a historical point of view it is much more important that he practices what he practices. But Weintraub's history is not a justification of social constructivism, nor does it vindicate meaning philosophy over realism. In fact, in his methodological pilgrimage Weintraub has not strayed very far from his Popperian and Lakatosian starting point. But the journey has not been in vain. Its result is that the past is not what it used to be. It has improved with age.

\section{References}

J. Birner 1993, "Neoclassical Economics as Mathematical Metaphysics", History of Political Economy

J. Birner 1993a, "Testing Economic Theories Empirically: The Contribution of Econometrics", Oekonomie und Gesellschaft

J. Birner forthcoming, Strategies and Programmes in Capital Theory; A Contribution to the Methodology of Theory Development (preliminary title), Routledge

J. Birner \& Van Zijp (eds.) 1993, Hayek, Co-ordination and evolution; His legacy in philosophy, politics, economics and the history of ideas, Routledge

M. Boumans 1992, A Case of Limited Physics Transfer; Jan Tinbergen's Resources for Re-shaping Economics, Ph.D. thesis, University of Amsterdam

N. de Marchi 1988, The Popperian legacy in economics, Cambridge University Press

E.J. Dijksterhuis 1952, "Clio's stiefkind" ("Clio's stepchild"), in Dijksterhuis 1990

E.J. Dijksterhuis 1990, Clio's stiefkind, edited by K. van 
Berkel, Bert Bakker

M.I. Finley, The World of Odysseus, Chatto \& Windus

F.A. Hayek 1974, "The Pretence of Knowledge" (Nobel memorial lecture), in Hayek 1978

F.A. Hayek 1978, New Studies in Philosophy, Politics, Economics and the History of Ideas, Routledge \& Kegan Paul

F.A. Hayek 1979, Law, Legisation and Liberty, Vol. 3, Routledge \& Kegan Paul

I. Lakatos 1971, "History of science and its rational reconstructions", in Lakatos 1978

I. Lakatos 1978, The methodology of scientific research programmes; Philosophical Papers Volume I, edited by J. Worrall \& G. Currie

P. Mirowski 1989, More heat than light, Cambridge University Press

P. Munz 1985, Our Knowledge of the Growth of Knowledge; Popper or Wittgenstein, Routledge \& Kegan Paul

K.R. Popper 1963, Conjectures and Refutations, Routledge \& Kegan Paul

K.R. Popper 1963a, "Why are the calculi of logic and mathematics applicable to reality?", in Popper 1963

K.R. Popper 1973, The Open Society and its Enemies, Routledge \& Kegan Paul

P.A. Samuelson 1983, Foundations of Economic Analysis; Enlarged Edition, Harvard University Press

R. van Zijp \& H. Visser 1993, "Mathematical formalization and the domain of economics: the case of Hayek and the New Classical Economics", in Birner \& Van Zijp 1993

E.R. Weintraub 1979, Microfoundations, Cambridge University Press

E.R. Weintraub 1985, General equilibrium analysis; Studies in appraisal, Cambridge University Press

E.R. Weintraub 1991, Stabilizing dynamics; Constructing economic knowledge, Cambridge University Press

E. Wigner 1960, "The Unreasonable Effectiveness of Mathematics in the Natural Sciences", Communications in Pure and Applied Mathematics

E. Zahar 1980, "Einstein, Meyerson and the Role of Mathematics 
in Physical Discovery", British Journal for the Philosophy of Science 